\title{
Jesus Martín Barbero e seus estudos de mediação na telenovela ${ }^{1}$
}

\author{
Jesus Martin Barbero and his studies of mediation in the telenovela \\ Luiza Carla Ribeiro ${ }^{2}$ \\ (luizaribeiro.rp@gmail.com) \\ Simone Antoniaci Tuzzo ${ }^{3}$ \\ (simonetuzzo@hotmail.com) \\ http://dx.doi.org/10.5216/cei.v16i2.29187
}

\section{Resumo}

Este trabalho tem como objetivo apontar as principais ideias do autor Jesus Martín Barbero, ressaltando a teoria das mediações e os estudos da recepção da telenovela. Neste âmbito, usamos como suporte teórico os estudos do autor compreendendo a comunicação como uma questão de cultura, não se restringindo somente ao que o emissor envia e sim ao que o receptor entende e faz com a mensagem. Para contemplar a compreensão do emissor, outro estudo levantado neste trabalho é a importância da telenovela na construção das identidades individuais e na interação com o cotidiano familiar devido aos temas retratados, que em sua maioria trás muito do que o indivíduo enfrenta na vida real. Trata-se de uma pesquisa bibliográfica que acredita que as telenovelas vão além do entretenimento.

Palavras-chave: Mediação. Telenovela. Recepção. Jesus Martín Barbero. Melodrama.

\begin{abstract}
This paper aims to point out the main ideias of the author Jesus Martin Barbero, emphasizing this theory of mediation and studies the reception of soap operas. In this context, we use a theoretical studies support the author' $s$ understanding communication as a matter of culture, not restricted only to the sender sends and yes to the receiver understands the message and makes. To address the understanding of the issuer, another study raised in this study is the importance of the telenovela in the construction of individual identities and interaction with every day family due to issues portrayed, which mostly behind much of what the individual faces in real life. It is a literature that believes telenovelas go beyond entertainment. It is a literature that believes telenovelas go beyond entertainment.
\end{abstract}

Keywords: Mediation. Telenovela. Reception. Jesus Martin Barbero. Melodrama.

\footnotetext{
${ }^{1}$ Trabalho desenvolvido dentro do Projeto de Pesquisa Rupturas Metodológicas para uma leitura crítica da Mídia entre os Programas de Pós-Graduação da UFG e UFRJ, que integra a ação transversal nº 06/2011 - Casadinho/Procad.

${ }^{2}$ Goiás Relações Públicas pela Universidade Federal de Goiás, Mestranda em Comunicação na linha de Mídia e Cidadania pela Universidade Federal.

${ }^{3}$ Doutora em Comunicação pela UFRJ, Mestre e Graduada em Comunicação pela UMESP, Coordenadora do Projeto de Pesquisa Rupturas Metodológicas para uma leitura crítica da Mídia entre os Programas de Pós-Graduação da UFG e UFRJ, que integra a ação transversal no 06/2011 - Casadinho/Procad. Professora e Orientadora do Trabalho.
} 


\title{
Introdução
}

Espanhol de Ávila, Jesus Martín Barbero escolheu a América Latina como sua morada no começo da década de 1960 quando se transferiu para Colômbia e a definiu como sua pátria. Começou ali o caminho que levaria ao status de um dos principais intelectuais do continente. Formou-se academicamente na Europa como doutor em Filosofia pelo Instituto de Filosofia de Lovaina, na Bélgica, e pós-doutorado em Semiótica e Antropologia na Escola de Altos Estudos de Paris.

Na América Latina, os estudos de recepção das mensagens começaram a se intensificar a partir dos anos de 1980. Antes predominavam estudos que consideravam os meios de comunicação como dominantes e o público como passivo. Um dos estudiosos que iniciou a ressaltar que o processo de recepção deve ser observado de maneira mais ampla foi Jesus Martín Barbero.

Barbero destaca-se como um dos precursores a introduzir no ambiente latino-americano a análise do processo de comunicação por meio de uma visão antropológica da cultura.

\begin{abstract}
Afirmamos que cultura não é apenas o que a sociologia chama de cultura, que são aquelas atividades, aquelas práticas, aqueles produtos que pertencem às belas artes e às belas letras, a literatura. Há uma concepção antropológica de cultura que está ligada as suas crenças, aos valores que orientam sua vida, à maneira como é expressa sua memória, os relatos de sua vida, suas narrações e também a música, atividades como bordar, pintar, ou seja, alargamos o conceito de cultura. (...) Com uma noção de cultura diferente, começamos a entender que, se era cultura, estava dentro da vida cotidiana. (MARTIN-BARBERO; BARCELOS, 2000, p. 157).
\end{abstract}

Ao contrário dos estudos clássicos de comunicação, que ignoram a ação de produção ou criatividade no processo de recepção, na pesquisa de Barbero, o receptor participa das mensagens e tem poder de produção o qual perpassa sua bagagem cultural, o processo comunicacional deve ser analisado como um todo. Com isso, de acordo com Barbero (1997), a recepção é sempre mediada por práticas cotidianas que estão inseridas no contexto cultural e social do sujeito receptor.

Percebe-se que para Barbero, a comunicação torna-se uma questão de mediação, onde o primordial nas pesquisas não se encontra entre os meios, mas nas relações sociais que ocorrem no processo de recepção. Podemos enfatizar, então, que a sociedade não é composta somente por mídia, e portanto há muito a ser observado. 
No longo caminho de Barbero, não há espaço para teorias sem mudanças e nem verdades absolutas. Pelo contrário, há a todo momento a realidade da América Latina e as contradições das teorias clássicas inquietam-no. Por isso, mudam-se a perspectiva dos olhares, os lugares das perguntas e das respostas. Neste contexto, o autor deixa de responder apenas o que "os meios fazem com as pessoas?", questão que ressalta as teorias anteriores e clássicas, e passa a questionar "o que as pessoas fazem com os meios?".

Entre seus principais estudos, Barbero também focou-se no gênero do melodrama. Ele vê com extrema importância a necessidade de se entender a telenovela na construção da identidade individual, principalmente dos povos latino-americanos. Segundo o autor, para muitos a telenovela significa a representação de si mesmo, tornando-se sua identidade.

A telenovela por muitas vezes faz o papel de cumprir um legado para além da diversão, identificando a realidade. Retrata fatos cotidianos, realidades vivenciadas que a maioria dos indivíduos acaba por se identificar. Isso pode ser percebido principalmente no Brasil, país em que a dramaturgia tem grande espaço na televisão, inclusive em horários nobres.

\section{Os conceitos de mediações e recepção em Jesus Martín Barbero}

O receptor da mensagem não somente se intitula como um indivíduo que recebe as mensagens, mas um sujeito capaz de participar do processo de comunicação. Isso é identificado no clássico livro de Barbero, De los meios a las mediaciones (1987). Neste trabalho, Barbero defende que os debates devem se concentrar passando dos meios para as mediações.

De acordo com Martin Barbero (1997), o processo da recepção é mediado por práticas rotineiras que estão inseridas dentro de um contexto social e cultural do sujeito que recebe a mensagem. Essas práticas estão constantemente presentes nas interpretações que os receptores fazem de um conteúdo midiático.

Levando o estudo de mediação para a televisão, Jesus Martín Barbero defende que ela não deve se restringir apenas a um assunto de comunicação. A televisão é primeiramente, cultural, e assim, poderia ser considerada como determinante nas discussões sobre política cultural.

A questão do popular não se restringe somente naquilo que é urbano e massivo, para o estudioso. A recepção para Martín-Barbero (2003) possui resistências, e com as divergências culturais 
estariam as pluralidades. Com este pensamento, a verdadeira luta dos indivíduos estaria hoje no campo da comunicação, não se restringindo a uma lógica unicamente geográfica ou política. Com países cada vez mais ligados entre si por meio das novas tecnologias, que por sua vez acaba diminuindo as distâncias e diferenças, a própria identidade e, mormente, a valorização do popular, poderiam ser destaque nos estudos de comunicação.

Como já destacado, para Barbero o receptor não é somente um mero receptor de informações produzidas pelos meios de comunicação, também é um produtor de significados, com isso o autor propõe um estudo transdisciplinar do campo comunicacional, envolvendo cultura e política. Barbero (1987) sugere três hipóteses de mediações que interferem e mudam a maneira como os receptores recebem os conteúdos dos meios. São eles: a cotidianidade familiar, a temporalidade social e a competência cultural.

A competência cultural deve ser entendida como a bagagem cultural que o indivíduo carrega ao longo da vida, não somente focando na educação formal, mas englobando as experiências adquiridas ao longo da vida. Martín Barbero critica a visão de que a televisão represente a decadência cultural. Segundo ele, a televisão não pode se aproximar do paradigma da arte, se tornando didática. Portanto, ele indaga se faz sentido ainda ficarem dúvidas teóricas sobre a inserção da televisão no patamar cultural, quando na verdade é a televisão uma das maiores responsáveis pela reprodução cultural.

Para Barbero, a temporalidade social diferencia o tempo produtivo do capital, o que sugere existir dois tempos. $\mathrm{O}$ autor enfatiza que o tempo em que se organiza a programação da televisão é constituído por ambos. Dessa forma, segundo ele, "A serie e os gêneros fazem agora a mediação entre o tempo do capital e o tempo da cotidianidade" (BARBERO, 1997, p. 296).

Já a cotidianidade familiar é o lugar onde as pessoas mostram quem realmente são por meio das relações sociais e da interação com os demais indivíduos e instituições. A cotidianidade familiar é considerada uma das mais importantes mediações para a recepção dos meios. Assim o é pelo fato de que a família representa um espaço de conflitos e tensões que, reproduzindo as manifestações de poder na sociedade, faz com que os indivíduos manifestem seus anseios e inquietações.

Com esse sentido, começou-se a ver a família como um lugar em que ocorre a leitura e a codificação das mensagens veiculadas nos meios de comunicação. Contudo a mediação da cotidianidade familiar não se restringe apenas aos discursos dos meios comunicacionais, mas como um espaço de relações mais próximas. 
Martín Barbero vem, desde esses primeiros estudos, repensando a teoria das mediações. Argumentando a centralidade dos meios perante a sociedade, o autor acrescenta o seu modelo, que antes era mais centrado na recepção e no consumo, para englobar uma análise mais específica dos meios. Em 1990, no artigo "De los médios a las practicas”, ele propõe que as três mediações fossem transformadas em três dimensões: socialidade, ritualidade e tecnicidade. A socialidade relaciona-se com a interação social preconizando as negociações do indivíduo com o poder e com as instituições. A ritualidade relaciona com as rotinas de trabalho e a produção cultural. E a tecnicidade remete a construção de outras práticas da lógica de produção por meio das diferentes linguagens do meio.

\section{A telenovela: o melodrama da televisão}

O melodrama, segundo Barbero (1987), surge em 1790, principalmente na França e na Inglaterra, representado na forma de teatro como um espetáculo popular, onde se discutia ou eram tema os novos padrões morais e comportamentais vigentes na época. $\mathrm{O}$ teatro acaba por representar grande parte da população que se identifica nos personagens e histórias comuns.

De acordo com Barbero, as peças populares estavam proibidas de entrar em cena por causa de ações do governo para tentar controlar o alvoroço do povo, com isso os teatros oficiais eram destinados somente à alta classe, e os espetáculos voltados às obras literárias. O que se destinou ao popular foram representações sem diálogos nas ruas e avenidas das cidades, denominadas de pantomimas.

As encenações pantomimas eram ao ar livre e teatralizavam o cotidiano de um povo, sua cultura e seus costumes. O modelo permitia que o indivíduo se identificasse naquela encenação, o que causava nele emoções.

As paixões políticas despertadas e as terríveis cenas vividas durante a Revolução exaltaram a imaginação e exacerbaram a sensacionalidade de certas massas populares que afinal podem se permitir encenar suas emoções. (...) Antes de ser um meio de propaganda o melodrama será o espelho de uma consciência coletiva. (BARBERO, 1987, p. 158).

O melodrama encenado pelo teatro naquela época tornou-se uma arte massiva, voltada para o povo, um gênero que se apresentará posteriormente no rádio e na televisão. Ao contrário das encenações do teatro da alta nobreza, o melodrama era alvoroço, emoção e gestos corporais.

Tendo como eixo central quatro sentimentos básicos - medo, entusiasmo, dor e riso - a ele correspondem quatro tipos de situações que são ao mesmo tempo sensações - terríveis, 
excitantes, ternas, e burlescas - personificadas ou "vividas" por quatro personagens - o Traidor, o Justiceiro, a Vítima, e o Bobo - que ao juntar-se realizam a mistura de quatro gêneros: romance de ação, epopéia, tragédia e comédia. Essa estrutura nos revela no melodrama uma tal pretensão de intensidade que só pode alcançar à custa da complexidade. (BARBERO, 1987, p. 162).

Neste cenário, o melodrama representa um gênero, conceito que o autor compreende como uma estratégia de comunicabilidade, o lugar das mediações em que se pode analisar os processos comunicacionais.

Nenhum outro gênero chegou a ser tão popular na América Latina como é o melodrama. Sobre esta popularidade Barbero (2001) enfatiza que o melodrama é o modo de expressão mais aberto a cultura de um povo, ao modo de viver e sentir da nossa gente. A maioria dos enredos no melodrama carrega muito do que somos e do que queremos nos tornar, por isso a essência desse gênero é o reconhecimento. Assim como o teatro representava para o povo sua própria identidade, as telenovelas assumem - já com a novela Beto Rockfeller em 1968 - também os costumes do cotidiano e demonstram nas telas o jeito de ser da cultura de um povo e com referências compartilhadas entre os povos.

No Brasil as telenovelas representam aspectos da cultura nacional, integrando e construindo ao mesmo tempo sua identidade. Além de ser um produto cultural, ela está interligada a realidade social dos sujeitos por meio das representações sociais. Perpassando a função de entretenimento ela espelha a realidade do cotidiano. Conflitos familiares, políticos e temas sociais são enredos de tramas de muita audiência.

Programas de televisão como a telenovela conseguem obter sucesso, destacar temáticas e narrativas que se relacionam ao cotidiano de seus receptores, proporcionando, portanto, as projeçõesidentificações do telespectador frente ao mundo de representação. Corroborando com esse pensamento, Morin (1997) destaca:

A projeção-identificação intervém em todas as relações humanas, desde que estas sejam coloridas de afetividade. (...) E por isso o imaginário se acha comprometido como tecido cotidiano de nossas vidas. (...) Os olimpianos, por meio de sua dupla natureza, divina e humana, efetuam a circulação permanente de projeção-identificação. Eles realizam os fantasmas que os mortais não podem realizar, mas chamam os mortais para realizar o imaginário. (MORIN, 1997, p. 101-107). 
O que parece acontecer é um contato direto entre aquele que produz novelas e aqueles que as assistem, esses receptores, embora desconheçam as regras para confecção de uma novela, conhecem a construção estética e a linguagem apresentadas.

Manoel Carlos, dramaturgo brasileiro é uma referência nessa área. $\mathrm{O}$ autor ficou conhecido por escrever novelas que discutiam assuntos sociais nas relações familiares. Em Mulheres Apaixonadas (2003) temas sociais e polêmicos entraram em cena, como lesbianismo, preconceito social e contra idoso, celibato e outros.

Quando Stuart Hall (1998) diz que a identidade é produto das interações sociais e que as culturas nacionais na qual nascemos e vivemos formam uma das mais importantes fontes da identidade cultural, ele corrobora com o meio que evidenciamos nessa parte do trabalho, a telenovela.

A telenovela se constitui como um dos produtos mais importante da televisão brasileira para a construção de uma identidade nacional, e com isso, afeta a construção da identidade do indivíduo. A telenovela fica em um patamar importante, porque ela é produtora de símbolos que influenciam identidades nacionais e individuais. Segundo Hall (1998), a identidade é um produto de interações, que pode acontecer por face a face ou acontecem pelas mediações.

Através dessa mediação a telenovela funciona como uma evasão do cotidiano, quando permite sonhar novos universos e ainda possibilita um ponto de partida para as discussões para assuntos sempre polêmicos ou pouco discutidos em sociedade.

\section{A influência da telenovela}

No livro Os exercícios do ver, Barbero e Rey (2004) destacam que para muitos estudiosos a influência dos meios de comunicação na formação e educação dos cidadãos por muitos autores é vista como frívola e fútil e desligar a televisão se configuraria então na única solução. Entretanto para os autores, esta atitude demonstra um pensamento reducionista e elitista, e que por muitas vezes o sistema escolar também é vítima. A solução não é desligar a TV, e sim torná-la de qualidade. O moderno aparelho de televisão faz parte da cultura das sociedades latino-americanas e jamais pode ser diagnosticado somente como um veículo alienante, precisa ser entendido também como um agente social, com interesses próprios e alguns legítimos. 
O fato é que a televisão é capaz de manipular as pessoas que realmente são manipuláveis. Por isso a grande importância de uma educação de qualidade, capaz de incitar pessoas a ter um pensamento crítico sobre aquilo que vê e ouve.

A grande importância no meio de comunicação é a forma e a qualidade que se produz a mensagem. Levando esse pensamento para televisão brasileira temos um cenário atual onde a maior parte dos programas não são educativos e nem possuem temas que proporcionam algum engrandecimento cultural. Esse é o problema, a má qualidade com que trabalham aqueles que detém o poder da informação como forma de alienação na construção da mensagem.

Uma das pesquisas mais importantes sobre o papel dos meios, principalmente a televisão é construída por Pierre Bourdieu (1997), que analisa a forma como os meios de comunicação reforçam as estruturas de dominação nas sociedades modernas. Seguindo o mesmo pensamento, Nestor Garcia Canclini (2002), indica que a maioria das investigações que dizem respeito aos meios de comunicação aponta que o rádio, a televisão e a imprensa, reproduzem muitos valores dominantes e não favorecem sua transformação. Portanto, Bourdieu e Canclini possuem pensamentos que coincidem ao afirmar a importância e influência que tem a televisão nas alterações sociais e culturais da modernidade.

Entre as variadas formas e expressões que os meios de comunicação proporcionam, a telenovela é uma das atrações que mais tem audiência por retratar temas atuais, situações e vivências quotidianas com as quais os telespectadores podem se identificar. Para muitos autores a maioria das telenovelas é importante, pois nelas são representadas as noções de direitos e deveres que integram a formação de cidadania no país. As telenovelas que foram e são veiculadas nos últimos tempos no Brasil, influenciam na modificação do comportamento das famílias, em fatores como a violência contra mulheres, controle da natalidade e filhos.

A telenovela se tornou um forte veículo no que diz respeito à formação da opinião pública, pois ela capta e expressa padrões de comportamento, produzindo sempre debates que giram em todo o país. Retratando problemas que se identificam com a maioria das pessoas, os indivíduos conseguem sempre se identificar com alguns personagens.

Essa aproximação de temas reais retratados nas novelas com a vida real é principalmente veiculado no horário em que a maioria das famílias estará em casa, que compreende o horário das 21 horas. Na Rede Globo, emissora brasileira, isso é bem evidenciado, pois a maioria das novelas das 21 horas causa polêmica e grande audiência. 
Nota-se que os assuntos levados do plano fictício para o real proporcionam aproximação ainda maior da população com esse gênero televisivo. As características de realidade dentro da telenovela provocam um processo em que o telespectador se identifica ou se projeta nas cenas com os personagens.

A identificação se dá através das características, tanto afetivas quanto físicas, presentes nas personagens que o público leva a sua própria vida. A projeção ocorre mediante aquelas ações menos possíveis de serem realizadas socialmente. Ao se projetarem os indivíduos aliviam as suas tensões diante de uma história narrada pela indústria cultural. (MORIN, 1981, p. 78).

O processo de identificação do indivíduo se dá então, pelos personagens das novelas que mais gostamos ou que nos identificamos. O individuo acaba formando sua conduta e princípios "novos", ao querer ser reconhecido como uma nova pessoa.

O processo de identificação ocorre quando o espectador assume o ponto de vista da pessoa ou da personagem, tomando-o para si como um reflexo de sua situação de vida. Já a projeção acontece quando o espectador projeta seus sentimentos sobre o sujeito ou personagem televisivo, amando aqueles que o outro ama, odiando da mesma forma que o outro odeia e assim por diante. Esses processos de identificação e de transferência referem-se a níveis muitas vezes inconscientes do espectador. Anteriormente, as projeções davam-se com deuses e heróis, com seus poderes sobre-humanos. Hoje, os heróis pertencem à indústria cultural, são as estrelas do cinema e das novelas, os ídolos do esporte e da música. Podemos projetar no ídolo da televisão não só nossos desejos, mas também, sobretudo, nossos medos, tristezas, incertezas e, principalmente, aquilo que não temos coragem de viver, ou não temos condições de fazer (ORMEZZANO, 2005, p. 3).

Dentre tantos personagens, sempre tem um que de alguma forma chama a atenção por se parecer ou querer ser igual a ele. A vida social se coloca dentro das figuras da ficção. A telenovela faz com que o público sinta-se capaz de fabricar um lugar social para ele, funciona como eficaz instância de socialização do mundo atual.

\section{Considerações finais}

Jesus Martín Barbero é um dos mais reconhecidos estudiosos dos estudos culturais na America Latina, e proporcionou grande visibilidade por meios de seus estudos na área da recepção da mensagem e o modo como esse receptor a vê. Isso é bem evidenciado quando analisamos os processos que acontecem na televisão, onde o indivíduo recebe a mensagem e discute depois com os outros membros da família ou vizinhos. 
Um dos gêneros que mais influenciam a vida dos sujeitos é a telenovela, pois são evidenciadas nas tramas assuntos que os indivíduos se identificam. Temas sociais que na maioria das famílias se encontram.

Através deste trabalho entendemos as telenovelas não mais como a reprodução de mau gosto e sem cultura e passamos a reconhecê-la como parte do projeto da junção cultural da nação. Sendo veiculada cotidianamente ela se torna parte da identidade dos indivíduos, corroborando para a construção de pensamentos.

\section{Referências}

BOURDIEU, Pierre. A representação política: elementos para uma teoria do campo político. In:

BOURDIEU, Pierre. O poder simbólico. Lisboa: Difel, 1990.

BOURDIEU, Pierre. Sobre a televisão. Rio de Janeiro: Jorge Zahar, 1997.

CANCLINI, Nestor García. Cidades e cidadãos imaginados pelos meios de comunicação. Opinião Pública, Campinas, v. 8, n. 1, p. 40-53, 2002.

HALL, Stuart. A identidade cultural na pós-modernidade. Rio de Janeiro: DP\&A Editora, 1998.

MARTIN-BARBERO, Jesús. De los medios a las mediaciones: comunicación, cultura y hegemonía. Barcelona: Gustavo Gili, 1987.

MARTIN-BARBERO, Jesús. Dos meios às mediações: comunicação, cultura e hegemonia. Rio de Janeiro: UFRJ, 1997.

MARTIN-BARBERO, Jesús. Pistas para entre-ver meios e mediações. In: Dos meios às mediações: comunicação, cultura e hegemonia. Rio de Janeiro: UFRJ, 2003. Prefacio à $5^{\text {a }}$ edição castelhana incluída na reimpressão.

MARTÍN-BARBERO, Jesús; REY, Germán. Os exercícios do ver: hegemonia audiovisual e ficção televisiva, 2. ed. São Paulo: Senac São Paulo, 2004.

MORIN, E. Cultura de massas no século XX: o espírito do tempo 1: neurose. 5. ed. Rio de Janeiro: Florense Universitária, 1981.

MORIN, E. Cultura de massa no século XX: o espírito do tempo 1: neurose. 9. ed. Rio de Janeiro: Forense Universitária, 1997. 
ORMEZZANO, Graciela; et al. Cultura e esterótipos veiculados pela televisão. In: CONGRESSO DE CIÊNCIAS DA COMUNICAÇÃO NA REGIÃO SUL, 8., Passo Fundo, 2005. Trabalho apresentado no grupo de trabalho de Audiovisual, Passo Fundo/RS, 2005. 